\title{
Immunopathogenic Background of Pars Planitis
}

\author{
Joanna Przeździecka-Dołyk ${ }^{1}$ (D) Agnieszka Wegrzyn ${ }^{2} \cdot$ Anna Turno-Kręcicka $^{1} \cdot$ \\ Marta Misiuk-Hojło ${ }^{1}$
}

Received: 27 October 2014/ Accepted: 29 April 2015/Published online: 5 October 2015

(c) The Author(s) 2015. This article is published with open access at Springerlink.com

\begin{abstract}
Pars planitis is defined as an intermediate uveitis of unknown background of systemic disease with characteristic formations such as vitreous snowballs, snowbanks and changes in peripheral retina. The incidence of pars planitis varies $2.4-15.4 \%$ of the uveitis patients. The pathogenesis of the disease is to be determined in future. Clinical and histopathological findings suggest an autoimmune etiology, most likely as a reaction to endogenous antigen of unknown source, with $\mathrm{T}$ cells predominant in both vitreous and pars plana infiltrations. $\mathrm{T}$ cells subsets play an important role as a memory-effector peripheral cell. Snowbanks are formed as an effect of post inflammatory glial proliferation of fibrous astrocytes. There is also a genetic predisposition for pars planitis by human leukocyte antigen and several other genes. A coexistence of multiple sclerosis and optic neuritis has been described in numerous studies. Epiretinal membrane, cataract, cystoid macular edema, retinal detachment, retinal vasculitis, neovascularization, vitreous peripheral traction, peripheral hole formation, vitreous hemorrhage, disc edema are common complications observed in pars planitis. There is a need to expand the knowledge of the pathogenic and immunologic background of the pars planitis to create an accurate pharmacological treatment.
\end{abstract}

Joanna Przeździecka-Dołyk

arie_1@wp.pl

1 Department and Clinic of Ophthalmology, Wroclaw Medical University, Borowska 213, 50-556 Wrocław, Poland

2 Department of Internal Medicine, Jagiellonian University, Kraków, Poland
Keywords Pars planitis .

Idiopathic uveitis intermedialis · Iris · Ciliary body · Immunology $\cdot$ Eye

\section{Introduction}

Intermediate uveitis described by the Standardization of Uveitis Nomenclature is the inflammation in the anterior vitreous, ciliary body and the peripheral retina, the vitreous is the major site of the inflammation. If there is a systemic disease (e.g., sarcoidosis) or associated infection (e.g., Lyme disease) (Bloch-Michel and Nussenblatt 1987; Jabs et al. 2005), the term idiopathic should not be used. There are many names that have been used to describe inflammation in the anterior vitreous, ciliary body and peripheral retina such as intermediate uveitis, pars planitis, chronic cyclitis, peripheral uveitis, vitritis, cyclochorioretinitis, chronic posterior cyclitis and peripheral uveoretinitis (Foster and Vitale 2013).

The diagnostic term "pars planitis" should be used only for an intermediate uveitis of unknown systemic disease (absence of any known systemic cause) or not related to any infection and where the snowbank or snowball formation is observed (Jabs et al. 2005).

There are limited data on incidence of pars planitis itself. Usually the reported epidemiology underlines incidence of intermediate uveitis (varying between 1.4 and $22 \%$ ) as a wider group and not pars planitis (Chan et al. 2007; Foster and Vitale 2013; Henderly et al. 1987; McCannel et al. 1996; Rodriguez et al. 1996).

The pathogenesis of the disease is to be determined in future. Clinical and histopathological findings suggest an autoimmune etiology, most likely as a reaction to endogenous antigen of unknown source, with $\mathrm{T}$ cells 
predominant in both vitreous and pars plana infiltrations. There is limited number of research where the study group includes only patients with pars planitis. Usually research includes patients with intermediate uveitis to the study group and sometimes subtracts a subgroup of patients with pars planitis.

The course of pars planitis and possible complications are well defined and were observed in many trials (Babu and Rathinam 2010; Donaldson et al. 2007; Eichenbaum et al. 1988; Felder and Brockhurst 1982; Foster and Vitale 2013; Green et al. 1981; Jabs et al. 2005; Kenyon et al. 1975; Malinowski et al. 1993a; Nussenblatt and Palestine 1989; Pederson et al. 1978; Pruett et al. 1974; Smith et al. 1976). However, the pathophysiology and possible impact of immune system to the course of the disease and to the complication are to be determined.

Aim of this paper is to summarize available knowledge of immunopathogenesis of pars planitis. The worldwide resources were searched using Medline, Web of Science, Scopus and worldwide websites. Searched terms include: "pars planitis", "intermediate uveitis", "uveitis" combined with "immunology", "immune response", "T cell", "B cell", "innate lymphoid cell" or with "flow cytometry" and in additional search only "experimental models of uveitis" as a single term searched.

Numerous papers were found but only few matched both criteria (approximately 25 items were founded). During the search for "experimental models of uveitis", task was easier to accomplish and items that were founded were numerous; approximately 17 of them were accurate for probable experimental models of intermediate uveitis or pars planitis. Founded papers focused on different aspects of the disease and define the study group differently. Most of them as patients with intermediate uveitis, some are subtracting a subgroup including patients suffering from pars planitis and few define study group as patients with pars planitis in the strict sense of this term presented previously.

Obtained data will be presented in sections entitled: epidemiology, pathogenesis, clinical features, complications and summary.

\section{Epidemiology}

Intermediate uveitis has been reported in 1.4-22\% of uveitis patients and there are limited data on the incidence of pars planitis (Chan et al. 2007; Foster and Vitale 2013; Henderly et al. 1987; McCannel et al. 1996; Rodriguez et al. 1996). The rate of 1.5 per 100,000 per year was reported by The Northern California Epidemiology of Uveitis Study (Gritz and Wong 2004). In tertiary referral centers, $2.4-15.4 \%$ of uveitis patients have been reported as the one with pars planitis diagnosis, but it must be taken under consideration that these centers observed more severe end of the spectrum of ocular inflammatory disease (Henderly et al. 1987; Wakefield et al. 1986).

\section{Pathogenesis}

\section{Immunological Background}

In healthy eye, an outer blood-retinal barrier (formed by tight junction of retinal pigmented epithelial cells and fenestrated choriocapillaris) as well as a blood-aqueous barrier (formed by tight junction of non-pigmented ciliary body epithelium and fenestrated endothelial cells) are considered responsible for immunological privilege. The inner bloodretinal barrier (formed by tight junction, non-fenestrated endothelium and astrocyte and Muller cell foot branches) acts as a true barrier (Shechter et al. 2013). Numerous immunomodulatory mediators, including: transforming growth factor (TGF)- $\beta$, membrane-bound TGF- $\beta$, interleukin (IL)-10, CD86, somatostatin, the enzyme thrombospondin, the apoptotic mediators FAS antigen ligand, tumor necrosis factor (TNF)-related apoptosis-inducting ligand, glucocorticoid-induced TNF-receptorrelated protein, programmed cell death 1 ligand, non-classical MHC class Ib molecules and the enzyme indoleamine2,3-dioxygenase can be found in both the outer bloodretinal barrier and the blood-aqueous barrier epithelial milieu (Kaur et al. 2008; Kerr et al. 2008; Streilein 2003; Sugita 2009; Sugita et al. 2006a; Sugita and Streilein 2003). Additionally, the iris, ciliary body and retinal pigment epithelium cells showed in vitro an ability to suppress the proliferation and activation of $\mathrm{T}$ cells either by direct cell to cell contact or by soluble factor-mediated mechanisms (Gregerson et al. 2007; Ishida et al. 2003; Kaur et al. 2008; Kerr et al. 2008; Sugita 2009; Sugita et al. 2006a). In some cases, retinal pigment epithelium (RPE) cells might convert effector $\mathrm{T}$ helper $(\mathrm{Th}) 1$ cells into regulatory $\mathrm{T}$ (Treg) cells (Sugita et al. 2004, 2006b; Yoshida et al. 2000a, b). RPE can also down regulate Th1 (Sugita et al. 2004), Th17 (Sugita et al. 2011), Th22 (Sugita et al. 2013b), CD8 ${ }^{+} \mathrm{T}$ cells (Sugita et al. 2006c), B cells (Sugita et al. 2010), macrophages (Zamiri et al. 2006) and dendritic cell (Sugita et al. 2013a) as well as up regulate Treg (Sugita et al. 2009, 2008) and suppressor myeloid cells (Tu et al. 2012).

Histopathological and clinical findings suggest a possible autoimmune etiology of pars planitis. In the infiltrate surrounding of the retinal vessels and in the snowbanks, the Th cells have been found. They can be possibly directed against some unknown ocular antigens (Wetzig et al. 1988; Yoser et al. 1992). The vitreoretinal interface, associated with retinal blood vessels, ciliary body, or the pars plana 
itself, may be the source of sought antigens (Davis et al. 1992).

Several experimental models of uveitis were described, used especially in cases of posterior uveitis, induced by a subcutaneous injection of single dose of soluble antigens (usually retinal). Mentioned models (see Table 1) include: experimental autoimmune uveitis (EAU) (Adamus and Chan 2002; Chan et al. 1985a, b; de Kozak et al. 1981), experimental melanin protein-induced uveitis (EMIU) (Adamus and Chan 2002; Matteson et al. 1999), experimental autoimmune encephalitis associated to anterior uveitis (EAE/AU) (Adamus et al. 2000; Adamus and Chan 2002; Buenafe et al. 1998) and endotoxin-induced uveitis (EIU) (Li et al. 1995). In each model, different soluble antigen is used; S-arrestin or interphotoreceptor retinoidbinding protein (IRBP), melanin proteins, myelin basic protein and lipopolysaccharide, respectively, for EAU, EMIU, EAE/AU and EIU (Gasparin et al. 2012). None of the described models fully explains the changes that occur in humans, especially in case of pars planitis. The possible candidates for pars planitis antigens were specified in conducted experiments involving humans. Those include human lens protein fraction (Doycheva et al. 2007), HNK-1 carbohydrate epitope (Uusitalo et al. 2000) and beta B1crystallin (Stempel et al. 2003).

The exact cause of pars planitis remains unknown (see Table 2), but $\mathrm{CD}^{+} \mathrm{T}$ cells that express an activation marker CD69 (an early activation marker) in either peripheral blood (Murphy et al. 2004) or in the aqueous humor are found, respectively, in patients with pars planitis and with idiopathic uveitis (Calder et al. 1999). Longitudinal measurements over a period of treatment rather than single evaluation of $\mathrm{CD} 4{ }^{+} \mathrm{CD} 69^{+} \mathrm{T}$ cells may be a useful substitute marker of ocular inflammation. As such it may be used to asses disease activity, but further studies are needed (Kilmartin et al. 2001; Murphy et al. 2004).

There are some studies showing increase in levels of surrogate markers of immune activation in the serum of patients with intermediate uveitis. These markers include IL-8 and soluble intracellular adhesion molecule 1 (Klok et al. 1998, 1999) as well as increased expression on peripheral $\mathrm{CD}^{+} \mathrm{T}$ cells such as soluble IL-2 receptor, HLA-DR and CD25 of patients with uveitis (Deschênes et al. 1988; Dick et al. 1992; Feron et al. 1995). All of mentioned above need to be confirmed in longitudinal studies before they become useful in clinical practice, in predicting an outcome of the disease and monitoring of the immunosuppressive treatment.

Studies of the model of experimental autoimmune uveitis have shown that Th1-related cytokines predominate in the active phase of the disease and IL-10 during resolution phase, indicating a shift towards Th2 (Barton et al. 1995). Further studies of peripheral blood $\mathrm{CD}^{+} \mathrm{T}$ cells expression of chemokines show no difference between the Th1-associated chemokine receptors CXCR3 and CCR5 or the Th2-associated chemokine receptor CCR4 in patients suffering from intermediate uveitis (enrollment of patients includes idiopathic and presumed sarcoid intermediate uveitis) compared to healthy controls as well as active compared to inactive disease (Murphy et al. 2004). Murphy et al. (2004) described an increase in the intracellular $\mathrm{CD}^{+}{ }^{+} \mathrm{T}$ cell expression of TNF- $\alpha$ in idiopathic intermediate uveitis which suggests a predominant $\mathrm{CD}^{+} \mathrm{T}$ cell subset and a new potential role of anti-TNF- $\alpha$ treatment in this type of uveitis (Sugita et al. 2006a).

In animal models of experimental autoimmune uveoretinitis, a transfer of $\mathrm{CD} 4{ }^{+} \mathrm{CD} 25^{\text {high }} \mathrm{Foxp}^{+}$Treg cells confer protection from uveitis induced by the uveitogenic retinal antigen IRBP (Keino et al. 2007; Siepmann et al. 2007; Silver et al. 2007). The lower percentage of CD4 ${ }^{+-}$ Foxp $3^{+}$T cells was observed in patients with active uveitis compared to inactive. However, no statistically significant differences were found in percentage of $\mathrm{CD} 4^{+} \mathrm{Foxp}^{+} \mathrm{T}$ cells between patients with known systemic autoimmune disease compared to idiopathic uveitis. The outcome was this same for patients with cystoid macular edema compared with no evidence of cystoid macular edema. In addition, no linear correlation of the percentage of $\mathrm{CD} 4^{+-}$ Foxp $3^{+} \mathrm{T}$ cells with $\log$ MAR best corrected visual acuity was observed (Yeh et al. 2009).

Until now, little is known about the role of $\mathrm{CD}^{+} \mathrm{T}$ cells in pars planitis, and of coexpression of functional $\mathrm{NK}$ receptors, like CD56 or CD57 on $\mathrm{CD}^{+} \mathrm{T}$ cells, which are thought to be associated with effector function of these cells (Ahn et al. 2005; Tarazona et al. 2000). Particularly CD57 expressed on both $\mathrm{CD}^{+}{ }^{+}$and $\mathrm{CD}^{+} \mathrm{T}$ cells is considered to be correlated with late immune responses (d'Angeac et al. 1994). Many studies have described an association between CD57 expression and persistent antigenic stimulation and chronic diseases. Pedroza-Seres et al. (2007) described in their paper a subset of CD57 ${ }^{+} \mathrm{T}$ cells. $\mathrm{CD}^{+} \mathrm{T}$ cells had a peripheral memory phenotype $\left(\mathrm{CCR}^{-} \mathrm{CD}^{-} 7^{-} \mathrm{CD} 28^{-}\right)$. The role of these cells in helper cell regulation was evaluated by cytokine production in $\mathrm{CD} 7^{+} \mathrm{T}$ cells. The intracellular proteins involved in cytotoxicity were measured in $\mathrm{CD}^{+} \mathrm{CD} 57^{+} \mathrm{T}$ cells and its elevated expression may suggest that these cells play an effector role in pars planitis (Pedroza-Seres et al. 2007). Also, in the model of experimental autoimmune uveitis, $\mathrm{CD}^{+} \mathrm{T}$ cells can be stimulated by IRPB and TGF- $\beta 1$ to express Foxp3 in high levels and may have suppressive functions (Peng et al. 2007).

Role of B cells was evaluated in studies performed on enucleated eyes, in case of infiltration of these cells in pars plana, vitreous and retina, but the results were not compared to immunological findings in the peripheral blood. In 


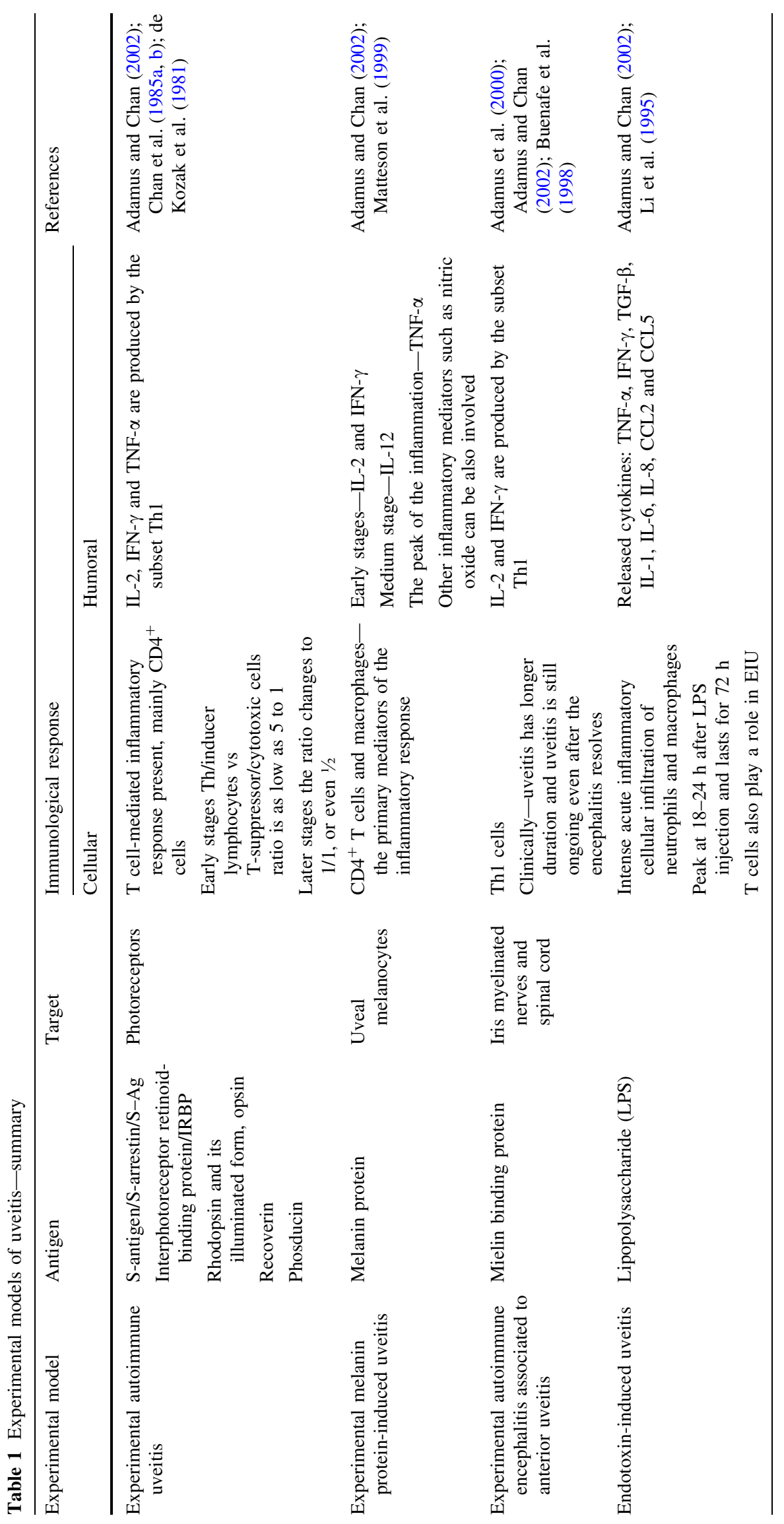




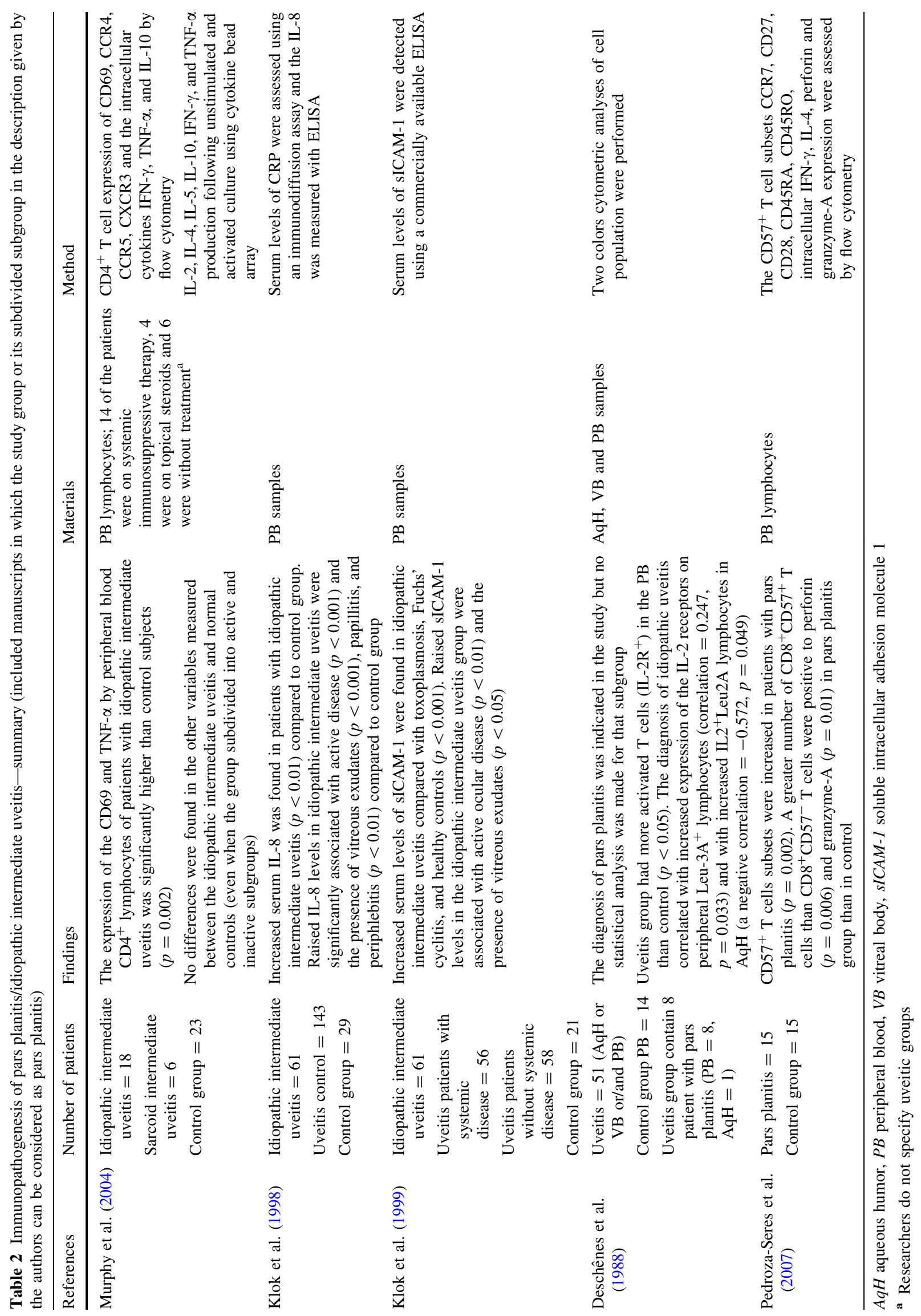


addition, the enucleated eyes were in last stage of the disease and nowadays with more efficient immunosuppressive treatment and wider range of possible surgical options, the stages usually are not recorded. Finally, the researches were conducted in the eighties of twentieth century and diagnostic possibilities have now improved.

The aspect of innate response in pars planitis was not taken into account in conducted researches, so far. The role of macrophages and neutrophils has not been evaluated so far. In the light of newly described innate lymphoid cells (ILCs) that have a function analogic to Th cells while also including NK cells, there will be a great demand of further research on ILCs in pars planitis.

From the point of view presented above, better understanding of immunological processes taking place in an affected eye during pars planitis may play a key role in pathogenesis of pars planitis and in appropriate treatment of this disease.

\section{Genetic Background}

There is also a genetic predisposition for the pars planitis. Number of studies described the contribution of the human leukocyte antigen (HLA) and several other genes in addition to those of the HLA in the pathogenesis of pars planitis. However, they differ in inclusion and exclusion criteria used to eliminate patients with intermediate uveitis due to other causes (e.g., sarcoidosis, syphilis) and described differences may play an important role why results of studies vary from each other. Several studies claimed the contribution of the HLA alleles considered as susceptibility markers in multiple sclerosis and optic neuritis which are: HLA-DR15, -DR51 and -DQ6 (Hillert et al. 1996; Malinowski et al. 1993b; Oruc et al. 2001; Raja et al. 1999; Tang et al. 1997). The subtype of intermediate uveitis was more often found in patients with multiple sclerosis (Bamford et al. 1978; Giles 1970; Porter 1972). An elevated frequency of HLA-B8, -B51 and -DR-2 was estimated after exclusion of patients with multiple sclerosis from the pars planitis group (Malinowski et al. 1993b). Some authors claimed that HLA-DR15, -DR51 and -DR17 contributed to the etiology of both multiple sclerosis and pars planitis (Oruc et al. 2001; Raja et al. 1999). Some studies evaluated a genetic predisposition of pars planitis and its course, for example, in Mexicans. HLA-A, -B, and $\mathrm{C}$ typing was done on $\mathrm{T}$ cells isolated with immunomagnetic beds from a group of untreated pars planitis patients with Mexican origins. The significant increase in frequency was found in DRB $1 * 0802$ in these patients. There was an association between clinical features, gender and HLA alleles (shown in Table 3; Alaez et al. 2003). Nonetheless, there can be found some studies that show no correlation between pars planitis and HLA alleles (Greiner et al. 2003; Mantrana-Bermejo et al. 2010).

\section{Clinical Features}

Patients with pars planitis usually present with minimal symptoms such as floaters or blurred vision. However, in severe cases, a significant visual loss can occur due to aggregation of floaters in the vitreous or due to macular oedema. The signs of inflammation from the anterior chamber may be minimal in the form of keratic precipitates, flare and cells or they may be absent. Sometimes we can also find posterior synechiae which are usually seen involving the inferior iris. A characteristic feature of pars planitis-vitritis is typically described and evaluated by clinicians as vitreous haze ranging from trace to $4+$ (Jabs et al. 2005).

The vitreous snowballs are yellow-white inflammatory aggregates which can be found in the midvitreous and inferior periphery (Felder and Brockhurst 1982; Nussenblatt and Palestine 1989; Pruett et al. 1974) (Figs. 1, 2). Some studies described vitreous snowballs as made of granulomatous inflammation (Green et al. 1981). The difficulty to get the material for further research precisely from intended spot results in lack of many molecular studies.

Snowbanks, the snow-white exudates that are found on the pars plana, usually are seen in the inferior area but they also can extend to $360^{\circ}$ of the retinal periphery. Typically they are associated with more severe forms of the disease, and require more aggressive therapy (Felder and Brockhurst 1982; Nussenblatt and Palestine 1989; Pruett et al. 1974). As previously described in histopathologic studies, snowbanks consist mainly of glial elements (probably fibrous astrocytes which can produce a large diameter collagen fibrils and basement membranes) (Eichenbaum et al. 1988; Green et al. 1981; Kenyon et al. 1975; Pederson et al. 1978), it was confirmed by staining with anti-Muller cell antibody and anti-glial fibrillary acid protein (GFAP). The formation of snowbanks is stimulated by inflammation. Activated Muller cells express class II MHC molecules and present antigen to $\mathrm{T}$ cells, sustaining an active state of inflammation itself (Roberge et al. 1985). The major collagen glycoproteins of snowbanks are type IV collagen and laminin (formed rather by glial cells than fibroblasts as the letter one's characteristic products are collagen type I and III). All these facts confirmed a hypothesis of postinflammatory glial proliferation that takes place in eye of pars planitis patients. Different results from the one's described above can be found in Abu ElAsrar and Geboes (2002) work. In their point of view, the snowbanks are an acellular formation (in exception of 


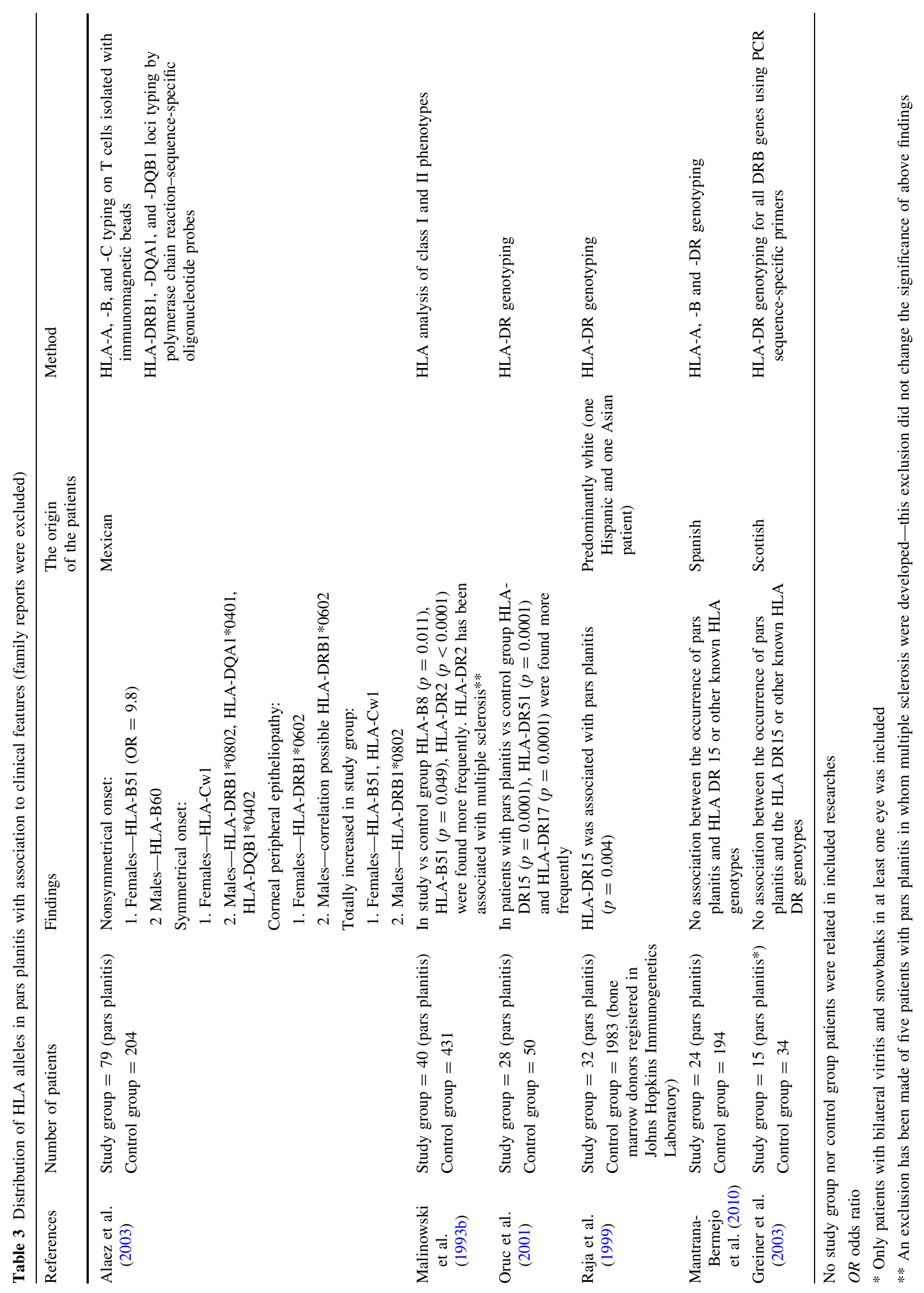




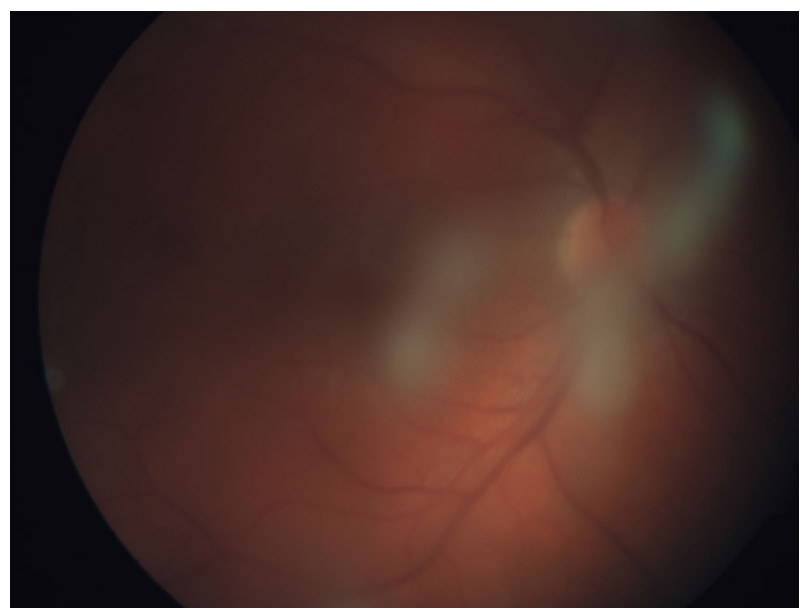

Fig. 1 16-year-old feme patient with diagnosed pars planitis, first ophthalmological examination. Snowballs are seen as focal yellowwhite massive exudates in peripheral anterior vitreous

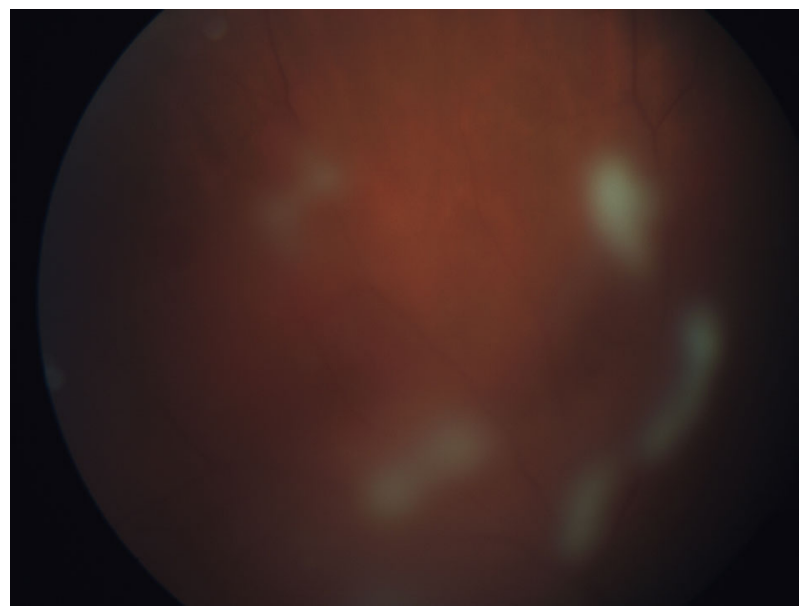

Fig. 2 Massive exudates in mid vitreous that block fundoscopic examination of posterior pole

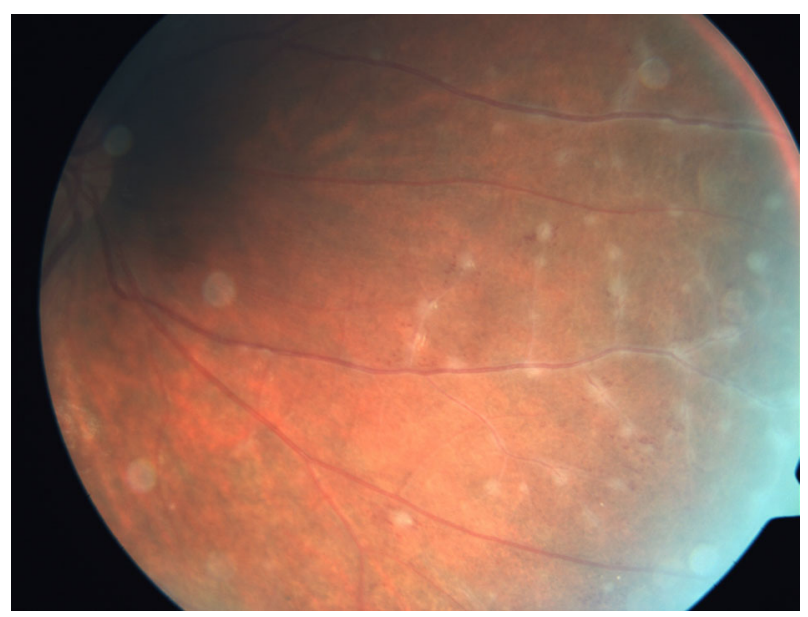

Fig. 3 17-year-old female patient with diagnosed multiple sclerosis, first ophthalmological examination. Vascular sheaths also known as vascular cuffs are seen as massive perivascular exudates uveal side cytokeratin-positive retinal pigment epithelial cells without cells positive for the GFAP and the myofibroblast cell marker alpha smooth muscle actin) containing tenascin and collagen type I, II and III, without the immunoreactivity of laminin or fibronectin (Abu El-Asrar and Geboes 2002).

Retinal changes in pars planitis occur in its peripheral part and include tortuosity of arterioles and venules, sheathing of veins (Fig. 3), neovascularization and sometimes retinal detachments (Felder and Brockhurst 1982; Nussenblatt and Palestine 1989; Pruett et al. 1974). The vascular sheathing in histopathologic studies presents a cellular infiltration dominated by $\mathrm{T}$ cells with few B cells usually posterior to the junction of the iris and ciliary body (Eichenbaum et al. 1988; Wetzig et al. 1988).

\section{Complications}

The most common ocular complication in patients with pars planitis is epiretinal membrane (ERM) with high incidence from 7 to $36 \%$ in different studies. The mean interval between onset of pars planitis and ERM was 6.5-7.9 years (Babu and Rathinam 2010; Donaldson et al. 2007; Malinowski et al. 1993a). The mechanism of epiretinal membrane formation during pars planitis is unknown.

Cataract was also common for pars planitis (frequency 14-30\%), it occured as a result of the disease and the treatment. It was difficult to distinguish between these too situations retrospectively. Most of the diagnosed cataracts were posterior subcapsular cataract followed closely by mixed nuclear sclerotic and posterior subcapsular cataracts. Described complications were developed much later, mean onset after presentation was 9.8 years (Babu and Rathinam 2010; Donaldson et al. 2007; Foster and Vitale 2013; Malinowski et al. 1993a; Pruett et al. 1974; Smith et al. 1976). The mechanism of steroid cataract induction remains unknown, nevertheless the observation of glucocorticoid-induced gene transcription and the finding of a transcriptionally active glucocorticoid receptor in human lens epithelial cells suggest that glucocorticoids can act directly in lens epithelial cells and modulate several signaling pathways influencing gene transcription (Dickerson et al. 1997; Gupta and Wagner 2009; James et al. 2003).

Cystoid macular edema (CME) was described as a major cause of visual loss (incidence 8-26\%) in patients with pars planitis (Fig. 4). The mean interval between onset of pars planitis and CME was 5.7 years (Babu and Rathinam 2010; Donaldson et al. 2007; Foster and Vitale 2013; Malinowski et al. 1993a; Pruett et al. 1974; Smith et al. 1976). The pathophysiology of cystoid macular edema was 


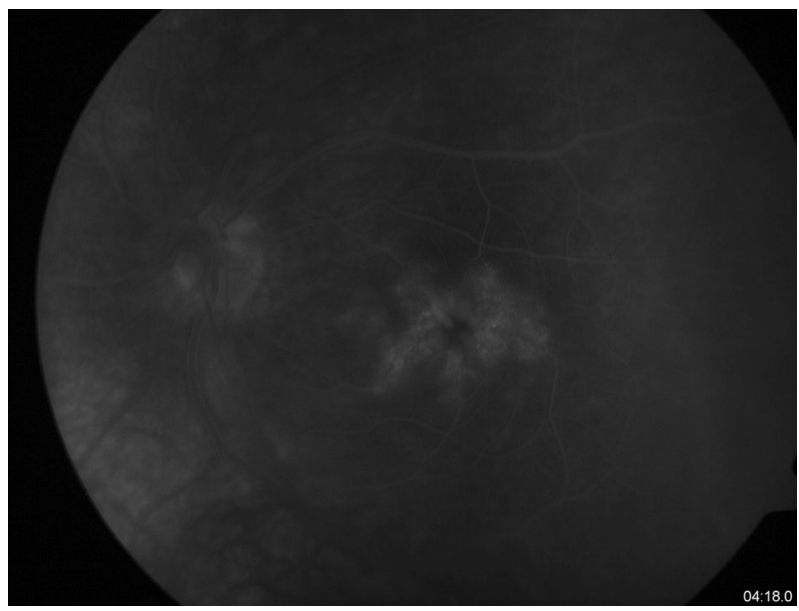

Fig. 4 Late phase of fluorescein angiography showing cystoid macular edema in 11-year-old boy with pars planitis

described in patients with uveitis without subdividing that group (no data show a pathomechanism of CME in patients with pars planitis). Retinal vascular hyperpermeability can be influenced by several mediators such as: nitric oxide, TNF- $\alpha$, vascular endothelial growth factors, prostaglandins, leukotrienes, cytokines IP-10 and IL-6 (Acharya et al. 2009; Curnow et al. 2005; Markomichelakis et al. 2005; Probst et al. 2004; van Kooij et al. 2006). Vascular leakage could result from endothelial cell damage (Leal et al. 2007).

The isolated cases of other complications occurring during onset of pars planitis as well as intermediate uveitis were registered in large researches, such as: retinal detachment (including exudative retinal detachment), retinal vasculitis, neovascularization, vitreous peripheral traction, peripheral hole formation, vitreous hemorrhage, disc edema, optic neuritis (Brockhurst and Schepens 1968; Deane and Rosenthal 1997; Donaldson et al. 2007; Malinowski et al. 1993a; Prieto et al. 2001; Pruett et al. 1974; Smith et al. 1976).

\section{Conclusion}

Little is known about background and pathology of pars planitis. From the patient and the ophthalmologist point of view, there is a great need for immunological research of this condition to improve the treatment.

Acknowledgments The current contribution is based on articles gathered by the authors from the worldwide web and original papers. This paper was written as an introduction to further studies of statutory activity conducted by Department and Clinic of Ophthalmology, Wroclaw Medical University in the field of uveitis.
Open Access This article is distributed under the terms of the Creative Commons Attribution 4.0 International License (http:// creativecommons.org/licenses/by/4.0/), which permits unrestricted use, distribution, and reproduction in any medium, provided you give appropriate credit to the original author(s) and the source, provide a link to the Creative Commons license, and indicate if changes were made.

\section{References}

Abu El-Asrar AM, Geboes K (2002) An immunohistochemical study of the "snowbank" in a case of pars planiti. Ocul Immunol Inflamm 10:117-123

Acharya NR, Hong KC, Lee SM (2009) Ranibizumab for refractory uveitis-related macular edema. Am J Ophthalmol 148(303-309):e2

Adamus G, Chan CC (2002) Experimental autoimmune uveitides: multiple antigens, diverse diseases. Int Rev Immunol 21:209-229

Adamus G, Manczak M, Sugden B et al (2000) Epitope recognition and $\mathrm{T}$ cell receptors in recurrent autoimmune anterior uveitis in Lewis rats immunized with myelin basic protein. J Neuroimmunol 108:122-130

Ahn JK, Chung H, Lee D et al (2005) CD8brightCD56 ${ }^{+} \mathrm{T}$ cells are cytotoxic effectors in patients with active Behcet's uveitis. J Immunol 175:6133-6142

Alaez C, Arellanes L, Vazquez A et al (2003) Classic Pars Planitis: strong correlation of class II genes with gender and some clinical features in Mexican Mestizos. Hum Immunol 64:965-972

Babu BM, Rathinam SR (2010) Intermediate uveitis. Indian J Ophthalmol 58:21-27

Bamford CR, Ganley JP, Sibley WA et al (1978) Uveitis, perivenous sheathing and multiple sclerosis. Neurology 28:119-124

Barton K, McLauchlan MT, Calder VL et al (1995) The kinetics of cytokine mRNA expression in the retina during experimental autoimmune uveoretinitis. Cell Immunol 164:133-140

Bloch-Michel E, Nussenblatt RB (1987) International Uveitis Study Group recommendations for the evaluation of intraocular inflammatory disease. Am J Ophthalmol 103:234-235

Brockhurst RJ, Schepens CL (1968) Uveitis. IV. Peripheral uveitis: the complications of retinal detachment. Arch Ophthalmol 80:747-753

Buenafe AC, Offner H, Machnicki M et al (1998) EAE TCR motifs and antigen recognition in myelin basic protein-induced anteri or uveitis in Lewis rats. J Immunol 161:2052-2059

Calder VL, Shaer B, Muhaya $M$ et al (1999) Increased CD4 ${ }^{+}$ expression and decreased IL-10 in the anterior chamber in idiopathic uveitis. Invest Ophthalmol Vis Sci 40:2019-2024

Chan CC, Mochizuki M, Nussenblatt RB et al (1985a) T-lymphocyte subsets in experimental autoimmune uveitis. Clin Immunol Immunopathol 35:103-110

Chan CC, Mochizuki M, Palestine AG et al (1985b) Kinetics of T-lymphocyte subsets in the eyes of Lewis rats with experimental autoimmune uveitis. Cell Immunol 96:430-434

Chan SM, Hudson M, Weis E (2007) Anterior and intermediate uveitis cases referred to a tertiary centre in Alberta. Can J Ophthalmol 42:860-864

Curnow SJ, Falciani F, Durrani OM et al (2005) Multiplex bead immunoassay analysis of aqueous humor reveals distinct cytokine profiles in uveitis. Invest Ophthalmol Vis Sci 46:4251-4259

D'Angeac AD, Monier S, Pilling D et al (1994) $\mathrm{CD}^{+} 7^{+} \mathrm{T}$ lymphocytes are derived from $\mathrm{CD}_{5}{ }^{-}$precursors by 
differentiation occurring in late immune responses. Eur $\mathrm{J}$ Immunol 24:1503-1511

Davis JL, Chan CC, Nussenblatt RB (1992) Immunology of intermediate uveitis. Dev Ophthalmol 23:71-85

De Kozak Y, Sakai J, Thillaye B et al (1981) S antigen-induced experimental autoimmune uveo-retinitis in rats. Curr Eye Res $1: 327-337$

Deane JS, Rosenthal AR (1997) Course and complications of intermediate uveitis. Acta Ophthalmol Scand 75:82-84

Deschênes J, Char DH, Kaleta S (1988) Activated T lymphocytes in uveitis. Br J Ophthalmol 72:83-87

Dick AD, Cheng YF, Purdie AT et al (1992) Immunocytochemical analysis of blood lymphocytes in uveitis. Eye 6(Pt 6):643-647

Dickerson JE, Dotzel E, Clark AF (1997) Steroid-induced cataract: new perspective from in vitro and lens culture studies. Exp Eye Res 65:507-516

Donaldson MJ, Pulido JS, Herman DC et al (2007) Pars planitis: a 20 -year study of incidence, clinical features, and outcomes. Am J Ophthalmol 144:812-817

Doycheva D, Deshka D, Preuss B et al (2007) High incidence of antibodies to lens proteins in sera from patients with uveitis. Graefes Arch Clin Exp Ophthalmol 245:683-688

Eichenbaum JW, Friedman AH, Mamelok AE (1988) A clinical and histopathological review of intermediate uveitis ("pars planitis"). Bull N Y Acad Med 64:164-174

Felder KS, Brockhurst RJ (1982) Neovascular fundus abnormalities in peripheral uveitis. Arch Ophthalmol 100:750-754

Feron EJ, Calder VL, Lightman SL (1995) Oligoclonal activation of $\mathrm{CD}^{+} \mathrm{T}$ lymphocytes in posterior uveitis. Clin Exp Immunol 99:412-418

Foster CS, Vitale AT (2013) Diagnosis and treatment of uveitis, 2nd edn. Jaypee Brothers Medical Publishers, New Delhi

Gasparin F, Takahashi BS, Scolari MR et al (2012) Experimental models of autoimmune inflammatory ocular diseases. Arq Bras Oftalmol 75:143-147

Giles CL (1970) Peripheral uveitis in patients with multiple sclerosis. Am J Ophthalmol 70:17-19

Green WR, Kincaid MC, Michels RG et al (1981) Pars planitis. Trans Ophthalmol Soc UK 101(Pt 3):361-367

Gregerson DS, Heuss ND, Lew KL et al (2007) Interaction of retinal pigmented epithelial cells and CD4 $\mathrm{T}$ cells leads to T-cell anergy. Invest Ophthalmol Vis Sci 48:4654-4663

Greiner KH, Wilson DW, Thomson J et al (2003) Genetic polymorphism of HLA DR in a Scottish population of patients with pars planitis. Eur J Ophthalmol 13:433-438

Gritz DC, Wong IG (2004) Incidence and prevalence of uveitis in Northern California; the Northern California epidemiology of uveitis study. Ophthalmology 111:491-500 (discussion 500)

Gupta V, Wagner BJ (2009) Search for a functional glucocorticoid receptor in the mammalian lens. Exp Eye Res 88:248-256

Henderly DE, Genstler AJ, Smith RE et al (1987) Changing patterns of uveitis. Am J Ophthalmol 103:131-136

Hillert J, Käll T, Olerup O et al (1996) Distribution of HLA-Dw2 in optic neuritis and multiple sclerosis indicates heterogeneity. Acta Neurol Scand 94:161-166

Ishida K, Panjwani N, Cao Z et al (2003) Participation of pigment epithelium in ocular immune privilege. 3. Epithelia cultured from iris, ciliary body, and retina suppress T-cell activation by partially non-overlapping mechanisms. Ocul Immunol Inflamm 11:91-105

Jabs DA, Nussenblatt RB, Rosenbaum JT (2005) Standardization of uveitis nomenclature for reporting clinical data. Results of the First International Workshop. Am J Ophthalmol 140:509-516

James ER, Robertson L, Ehlert E et al (2003) Presence of a transcriptionally active glucocorticoid receptor alpha in lens epithelial cells. Invest Ophthalmol Vis Sci 44:5269-5276
Kaur C, Foulds WS, Ling EA (2008) Blood-retinal barrier in hypoxic ischaemic conditions: basic concepts, clinical features and management. Prog Retin Eye Res 27:622-647

Keino H, Takeuchi M, Usui Y et al (2007) Supplementation of $\mathrm{CD} 4{ }^{+} \mathrm{CD} 25^{+}$regulatory $\mathrm{T}$ cells suppresses experimental autoimmune uveoretinitis. Br J Ophthalmol 91:105-110

Kenyon KR, Pederson JE, Green WR et al (1975) Fibroglial proliferation in pars planitis. Trans Ophthalmol Soc UK 95:391-397

Kerr EC, Copland DA, Dick AD et al (2008) The dynamics of leukocyte infiltration in experimental autoimmune uveoretinitis. Prog Retin Eye Res 27:527-535

Kilmartin DJ, Fletcher ZJ, Almeida JA et al (2001) CD69 expression on peripheral $\mathrm{CD}^{+} \mathrm{T}$ cells parallels disease activity and is reduced by mycophenolate mofetil therapy in uveitis. Invest Ophthalmol Vis Sci 42:1285-1292

Klok AM, Luyendijk L, Zaal MJ et al (1998) Elevated serum IL-8 levels are associated with disease activity in idiopathic intermediate uveitis. Br J Ophthalmol 82:871-874

Klok AM, Luyendijk L, Zaal MJ et al (1999) Soluble ICAM-1 serum levels in patients with intermediate uveitis. $\mathrm{Br} \mathrm{J}$ Ophthalmol $83: 847-851$

Leal EC, Manivannan A, Hosoya KI et al (2007) Inducible nitric oxide synthase isoform is a key mediator of leukostasis and blood-retinal barrier breakdown in diabetic retinopathy. Invest Ophthalmol Vis Sci 48:5257-5265

Li Q, Peng B, Whitcup SM et al (1995) Endotoxin induced uveitis in the mouse: susceptibility and genetic control. Exp Eye Res 61:629-632

Malinowski SM, Pulido JS, Folk JC (1993a) Long-term visual outcome and complications associated with pars planitis. Ophthalmology 100:818-824 (discussion 825)

Malinowski SM, Pulido JS, Goeken NE et al (1993b) The association of HLA-B8, B51, DR2, and multiple sclerosis in pars planitis. Ophthalmology 100:1199-1205

Mantrana-Bermejo ME, Rueda-Rueda T, Bernabeu-Wittel $\mathrm{J}$ et al (2010) Clinical and epidemiological features and HLA association in patients with pars planitis. Med Clínica 135:205-208

Markomichelakis NN, Theodossiadis PG, Sfikakis PP (2005) Regression of neovascular age-related macular degeneration following infliximab therapy. Am J Ophthalmol 139:537-540

Matteson DM, Shen DF, Chan CC (1999) Inhibition of experimental melanin protein-induced uveitis (EMIU) by targeting nitric oxide via phosphatidylcholine-specific phospholipase C. J Autoimmun 13:197-204

McCannel CA, Holland GN, Helm CJ et al (1996) Causes of uveitis in the general practice of ophthalmology. UCLA CommunityBased Uveitis Study Group. Am J Ophthalmol 121:35-46

Murphy CC, Duncan L, Forrester JV et al (2004) Systemic CD4(+) T cell phenotype and activation status in intermediate uveitis. Br J Ophthalmol 88:412-416

Nussenblatt RB, Palestine AG (1989) Uveitis: fundamentals and clinical practice. Year Book Medical Publishers, Chicago

Oruc S, Duffy BF, Mohanakumar T et al (2001) The association of HLA class II with pars planitis. Am J Ophthalmol 131:657-659

Pederson JE, Kenyon KR, Green WR et al (1978) Pathology of pars planitis. Am J Ophthalmol 86:762-774

Pedroza-Seres M, Linares M, Voorduin S et al (2007) Pars planitis is associated with an increased frequency of effector-memory $\mathrm{CD} 7^{+} \mathrm{T}$ cells. Br J Ophthalmol 91:1393-1398

Peng Y, Shao H, Ke Y et al (2007) Minimally activated CD8 autoreactive $\mathrm{T}$ cells specific for IRBP express a high level of Foxp3 and are functionally suppressive. Invest Ophthalmol Vis Sci 48:2178-2184

Porter R (1972) Uveitis in association with multiple sclerosis. Br J Ophthalmol 56:478-481 
Prieto JF, Dios E, Gutierrez JM et al (2001) Pars planitis: epidemiology, treatment, and association with multiple sclerosis. Ocul Immunol Inflamm 9:93-102

Probst K, Fijnheer R, Rothova A (2004) Endothelial cell activation and hypercoagulability in ocular Behçet's disease. Am J Ophthalmol 137:850-857

Pruett RC, Brockhurst J, Letts NF (1974) Fluorescein angiography of peripheral uveitis. Am J Ophthalmol 77:448-453

Raja SC, Jabs DA, Dunn JP et al (1999) Pars planitis: clinical features and class II HLA associations. Ophthalmology 106:594-599

Roberge FG, Caspi RR, Chan CC et al (1985) Long-term culture of Muller cells from adult rats in the presence of activated lymphocytes/monocytes products. Curr Eye Res 4:975-982

Rodriguez A, Calonge M, Pedroza-Seres M et al (1996) Referral patterns of uveitis in a tertiary eye care center. Arch Ophthalmol 114:593-599

Shechter R, London A, Schwartz M (2013) Orchestrated leukocyte recruitment to immune-privileged sites: absolute barriers versus educational gates. Nat Rev Immunol 13:206-218

Siepmann K, Biester S, Plsková J et al (2007) $\mathrm{CD}^{+} \mathrm{CD} 25^{+} \mathrm{T}$ regulatory cells induced by LPS-activated bone marrow dendritic cells suppress experimental autoimmune uveoretinitis in vivo. Graefes Arch Clin Exp Ophthalmol 245:221-229

Silver PB, Agarwal RK, Su SB et al (2007) Hydrodynamic vaccination with DNA encoding an immunologically privileged retinal antigen protects from autoimmunity through induction of regulatory T cells. J Immunol 179:5146-5158

Smith RE, Godfrey WA, Kimura SJ (1976) Complications of chronic cyclitis. Am J Ophthalmol 82:277-282

Stempel D, Sandusky H, Lampi K et al (2003) BetaB 1-crystallin: identification of a candidate ciliary body uveitis antigen. Invest Ophthalmol Vis Sci 44:203-209

Streilein JW (2003) Ocular immune privilege: therapeutic opportunities from an experiment of nature. Nat Rev Immunol 3:879-889

Sugita S (2009) Role of ocular pigment epithelial cells in immune privilege. Arch Immunol Ther Exp 57:263-268

Sugita S, Streilein JW (2003) Iris pigment epithelium expressing CD86 (B7-2) directly suppresses $\mathrm{T}$ cell activation in vitro via binding to cytotoxic $\mathrm{T}$ lymphocyte-associated antigen 4. J Exp Med 198:161-171

Sugita S, Ng TF, Schwartzkopff J et al (2004) CTLA- ${ }^{+} \mathrm{CD} 8^{+}$T cells that encounter B7.2 $2^{+}$iris pigment epithelial cells express their own B7.2 to achieve global suppression of $\mathrm{T}$ cell activation. J Immunol 172:4184-4194

Sugita S, Futagami Y, Smith SB et al (2006a) Retinal and ciliary body pigment epithelium suppress activation of $\mathrm{T}$ lymphocytes via transforming growth factor beta. Exp Eye Res 83:1459-1471

Sugita S, Keino H, Futagami $\mathrm{Y}$ et al $(2006 \mathrm{~b}) \mathrm{B}^{+}$iris pigment epithelial cells convert $\mathrm{T}$ cells into CTLA- $4^{+}$, B7-expressing $\mathrm{CD}^{+}$regulatory $\mathrm{T}$ cells. Invest Ophthalmol Vis Sci 47:5376-5384

Sugita S, Ng TF, Lucas PJ et al (2006c) $\mathrm{B}^{+}$iris pigment epithelium induce $\mathrm{CD}^{+} \mathrm{T}$ regulatory cells; both suppress $\mathrm{CTLA}-4^{+} \mathrm{T}$ cells. J Immunol 176:118-127

Sugita S, Horie S, Nakamura $O$ et al (2008) Retinal pigment epithelium-derived CTLA-2alpha induces TGFbeta-producing T regulatory cells. J Immunol 181:7525-7536
Sugita S, Horie S, Nakamura O et al (2009) Acquisition of $\mathrm{T}$ regulatory function in cathepsin $\mathrm{L}$-inhibited $\mathrm{T}$ cells by eyederived CTLA-2alpha during inflammatory conditions. J Immunol 183:5013-5022

Sugita S, Horie S, Yamada Y et al (2010) Inhibition of B-cell activation by retinal pigment epithelium. Invest Ophthalmol Vis Sci 51:5783-5788

Sugita S, Horie S, Yamada Y et al (2011) Suppression of interleukin17-producing T-helper 17 cells by retinal pigment epithelial cells. Jpn J Ophthalmol 55:565-575

Sugita S, Kawazoe Y, Imai A et al (2013a) Mature dendritic cell suppression by IL-1 receptor antagonist on retinal pigment epithelium cells. Invest Ophthalmol Vis Sci 54:3240-3249

Sugita S, Kawazoe Y, Imai A et al (2013b) Suppression of IL-22producing $\mathrm{T}$ helper 22 cells by RPE cells via PD-L1/PD-1 interactions. Invest Ophthalmol Vis Sci 54:6926-6933

Tang WM, Pulido JS, Eckels DD et al (1997) The association of HLA-DR15 and intermediate uveitis. Am J Ophthalmol 123:70-75

Tarazona R, DelaRosa O, Alonso C et al (2000) Increased expression of NK cell markers on $\mathrm{T}$ lymphocytes in aging and chronic activation of the immune system reflects the accumulation of effector/senescent T cells. Mech Ageing Dev 121:77-88

Tu Z, Li Y, Smith D et al (2012) Myeloid suppressor cells induced by retinal pigment epithelial cells inhibit autoreactive T-cell responses that lead to experimental autoimmune uveitis. Invest Ophthalmol Vis Sci 53:959-966

Uusitalo M, Mikkilä H, Karma A et al (2000) Search for autoantibodies against the HNK-1 carbohydrate epitope in the human eye in intermediate uveitis. Acta Ophthalmol Scand 78:536-538

Van Kooij B, Rothova A, Rijkers GT et al (2006) Distinct cytokine and chemokine profiles in the aqueous of patients with uveitis and cystoid macular edema. Am J Ophthalmol 142:192-194

Wakefield D, Dunlop I, McCluskey PJ et al (1986) Uveitis: aetiology and disease associations in an Australian population. Aust NZ J Ophthalmol 14:181-187

Wetzig RP, Chan CC, Nussenblatt RB et al (1988) Clinical and immunopathological studies of pars planitis in a family. $\mathrm{Br} \mathrm{J}$ Ophthalmol 72:5-10

Yeh S, Li Z, Forooghian F et al (2009) $\mathrm{CD}^{+}{ }^{+}$Foxp $3^{+}$T-regulatory cells in noninfectious uveitis. Arch Ophthalmol 127:407-413

Yoser SL, Forster DJ, Rao NA (1992) Pathology of intermediate uveitis. Dev Ophthalmol 23:60-70

Yoshida M, Kezuka T, Streilein JW (2000a) Participation of pigment epithelium of iris and ciliary body in ocular immune privilege. 2 . Generation of TGF-beta-producing regulatory $\mathrm{T}$ cells. Invest Ophthalmol Vis Sci 41:3862-3870

Yoshida M, Takeuchi M, Streilein JW (2000b) Participation of pigment epithelium of iris and ciliary body in ocular immune privilege. 1. Inhibition of T-cell activation in vitro by direct cellto-cell contact. Invest Ophthalmol Vis Sci 41:811-821

Zamiri P, Masli S, Streilein JW et al (2006) Pigment epithelial growth factor suppresses inflammation by modulating macrophage activation. Invest Ophthalmol Vis Sci 47:3912-3918 